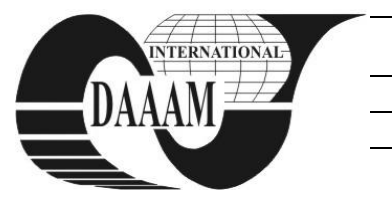

\title{
GENERAL ASPECTS ON THE INFLUENCE OF THE MODERN BIO-MEDICAL TECHNIQUES ON THE HUMAN BODY
}

\author{
PUSCA, F[lorentina]; BOROI, A[lexandru]; DUMITRACHE, A[na] - A[lina]; \\ POCORA, M[onica] \& CHIRILA, A[ngelica] D[aniela]
}

\begin{abstract}
Human life is inseparably corporal and spiritual concurrently. In the virtue of its substantial communion with the spiritual element, the human body cannot be considered to be just a complex of tissue, organs and functions and cannot be put on the same level with animal bodies, but is a constitutive part of the person through which it is manifested and expressed. It is truism that the science, expression of human knowledge is necessary, infinite and independent from ethical messages. Science has multiplied the creating powers of humans and social progress but also created destructive risks for humans and environment, for the genetic diversity of nature, even for the survival of the species.
\end{abstract}

Key words: human life, bio-medical techniques, human cloning

\section{INTRODUCTION}

Divinity created the world out on nothing. The human, creating himself, acquired thought and feeling that, although seem to be independent, have been limited by the restrictions and prescriptions imposed by society. In this sense, in the relation individual- society, the concept of society reflects certain dominant fundamental rules and principles or systems of values that characterize social life. The objective causes and especially the social ones determine the different human behavior and manners of actions so that the social restrictions acquire a mandatory normative aspect. The general argument resulting from the relations of the individual with the society consists in the fact that society develops in a positive manner because, within the complex process of education, the individual integrates in the normative and evolutional structure of society (Tanasescu et al., 2000).

\section{GENERAL ASPECTS ON THE INFLUENTS OF THE MODERN BIO-MEDICAL}

Even if through inferior human behavior social contradictions can be reached, manifested through different forms, through social processing the essence of a social existence is accomplished, in which these particular acts are included, condensed in the general undisputable manifestations of the individuals (Stoica Constantin \& Neculau, 1998). For this reason, a faulty individual behavior, in comparison with others more organized, once punished becomes an integrant part of the social system, dynamic, integrator in the human action phenomenon. The process of differentiation and integration of the individual behaviors contributes to the appearance and identification of some behavior patterns of maximum complexity that, although having a lot of meanings and significations (Dobrinoiu et. al, 2004) still have an intrinsic rationality in which the behavioral balance is identified under the shape of general social requests. The individual behavior becomes more the result of learning rather than heredity so that, if under the aspect of the reaction pattern to external stimulations, it does not seem to have a special signification, regarding the creation of a behavioral prototype of a crowd, or society, it represents the basic rule according to which its members act relatively stable and constant. Within the human behavioral structure, both biological and educational elements are included. The behavioral phenomenon, structuring actions and individual reactions as a manner of human interaction, is protected under the aspect of dignity and identity of the human being. Science has discovered that life appeared together with the matter, in its constant quest for the pair of lonely electrons, has combined three lifeless molecules into a bio-molecule. These three molecules were nitrogen, a pentose and a phosphate. The bio molecule created macromolecules representing proteins, carbohydrate and fat that, acting as enzymes, transporters, hormones, receptors and antibodies, organized in a cell. The humans are composed of tens of billions of these cells and the brain contains a hundred billions. The inorganic matter is infinite. Life is the transient biological phenomenon in which the inorganic turned into organic maintains itself independent until the return in inorganic matter. Any human person contains not only spirit but also body and through the body, the person itself is accomplished in its concrete reality.

The most authentic expression of the technical- scientific contemporary revolution is genetic discoveries that have placed bioethics in the paroxysmal situation of their human significance as the genetic research transcends the individual sphere and can become sources of public anguish both for the horizontal effects (in family) as well as vertical (descendent), both for private life and individual as well as for the community. The contemporary doctrine sustained that the human body can be considered a thing, but not any ordinary thing. The civil code provisioned that only things that are commercially can be the subject of conventions, which lead to the following statement: "in situations in which the human body cannot make the object of conventions, this could be due to the fact that it is a trade off - but a thing". Is the person the owner of his/ her body or a simple user? The human body is not a thing, is the person itself. If we would recognize the individual a right of property on his body, it means that we have to consider as being valid all their related and specific dispositional acts.

The human body cannot represent an object of law and the human, assimilated to the physical person, cannot be but a subject of law and not an object of law. In this context, the human body, complete and viable, in the actual conception of doctrine and jurisprudence, cannot be sold or donated because it would mean the reestablishment of slavery and turn the person in an object of property rights, while the elements of the human body can, in exceptional cases, make the object of acts of dispositions, in the extent allowed by law, because they are not a person in the judicial sense of the word. This situation can be analyzed from the perspective of personal anthropology, according to which the fetus and embryo have the value of a person, the slave of yesterday, deprived from the value of person and the recognition of the dignity of the person can today be the embryo frozen and used for experiments. The jurists have opposed to the accreditation of the right of the 
individual to dispose of their own body, motivating the fact that this type of recognition would lead to the self degradation of humans. Modern biotechnology has indicated that it can become one of the possible motors of the development of society in the third millennium, being compared with revolutionary methods that have changed human society forever such as the Great Industrial Revolution, the discovery of the atomic bomb or spatial research, promises a considerable medical progress and a possible improvement of the human condition but at the same time, has the potential to create unwanted or unpredictable problems with an impact that can be deep on the right to life, corporal integrity and health of individuals, human dignity but also on the structure of society as we know it now. In its wider sense, the concept of "biotechnology" refers to the technologies using living organisms (virus, bacteria, animal or vegetal cells coming from simple or complex organisms) or their sub cellular components purified in order to obtain useful stocks of commercial products, in order to improve the characteristics of plants, animals or humans or to create microorganisms for specific purposes (Bustamante \& Bowra, 2002). The progress registered by molecular biology beginning with the discovery and functioning of DNA in 1953 and continuing with the discovery of the human genome and also of multiple genetic structures of other animal species has represented the basis of necessary knowledge in order to make the profile, copy and manipulate the genotype of plants, animals and humans. This allows a wide variety of very advanced biotechnological techniques, including: Gene therapy for the diagnosis and treatment of disease; Fabrication of medicine for treating specific disease; Genetic identification in order to help solving cases in civil or criminal law; Biosensors created by genetic engineering for a variety of applications; Cloning in order to reproduce genetically identical organisms (reproductive cloning) or transplant organs (therapeutic reproduction); Genetically modified organisms in order to convert specific properties for certain purposes. All these techniques leading to the appearance of a multitude of products and a new industry and to the disappearance of others have not only a potentially positive effect but also a deep negative one. In order to prevent the negative consequence of using biotechnology and prevent serious problems that could emerge, many states have adopted criminal dispositions against genetic manipulation and the funding of scientific research in cloning was forbidden. The former president of the United States of America, Bill Clinton said: "We have to accept the serious ethical and moral issued raise by this extraordinary revolution". Same as the former American president, the British premier Tony Blair underlined that "humanity has the duty to use the new valuable information in a responsible manner and for the benefit of the entire humanity. Numerous conflicts have arisen as a result of ethical medicine development reproductive. Most call into question the right of individuals to control not their own body but also the fate of embryos resulting from their sex cells. But the most controversial issue raises the fate of surplus embryos produced by fertilization in vitro and reimplanted. They have to be destroyed or to be preserved and for what purpose? Can they be used in the cosmetic industry or this method constitutes a serious violation of principles of natural law? Have they the rights of a human being? Those who accept the use of new reproductive technologies agree that there are risks, misinformation and abuse, but which can be remedied by will, counseling, social responsibility and oversight of practitioners of research on reproduction.

The most important thing is that no matter how and where development begins, whether it is genetic or artificial insemination or not, whatever we do, everything will get anyone with any reproductive technology, is an unpredictable son or a daughter, not different of any other children. Reproductive technologies are irrelevant to society. They help individuals to found families. In vitro fertilization was to destroy the society 30 years ago, but it has no effect on people who do not need it. Should committees of experts, lawyers, scientists dealing with other issues to be involved in determining the morality of different ways in which people decide for themselves?

\section{CONCLUSION}

Concerning application of new scientific technologies in law, is to note their usefulness in ensuring, in a higher coefficient, the truth and to reduce the margin of error in protecting judicial bodies of false accusations of abuse. Therefore, not technology itself must be rejected, but their incorrect application in conflict with human rights. New technologies should avoid the uncertain feelings of public opinion, which oscillates between the desire for progress and the fear of development. Human cloning is one of the greater issues that has been raised and continues to be raised in modern science but also regarding political decisions. As John Harris suggestively indicated, "We are on the verge of a major breakthrough. The revolution in molecular and genetic biology will give us the possibility to deviate and control human evolution in an unprecedented measure. It will give us the possibility to create new forms of life that will put order in all the existing forms of life. The decision we are about to make does not entail if we are to use this solution or not but how and to what extent. Of course that it would have been easier to pretend that the revolution did not take place and continue to live as before but it would be useless and it would involve us in causing enormous suffering that could be avoided.

There is no secure way. If we won't succeed in producing change at the level of human beings, the result might be even worse than it should be, in the future. If we make incorrect modifications, we will find ourselves in the same situation.

I believe that we should learn to take responsibility and stop considering that not doing anything is wiser than doing something".

\section{REFERENCES}

Askenasy, J. (2007). The Brain and It s Universe. Bucuresti: Hasefer

Avram, A. (2000). The Genetic Revolution. Citidianul

Bustamante, P. I. \& Bowra, S. (2002). Biotechnology in developing countries: harnessing the potential of HIGH TECH SMES in the face of global competition. Electronic Journal of Biotechnology, pp. 197-202

Cosmovici, A. (1996). General Psychology. Iasi: Polirom.

Dobrinoiu, V. et. al. (2004). Drept penal, partea speciala. Bucuresti: Lumina Lex

Francioni, F. (2007). Biotechnology and International Human Rights. Oxford: Hard Publishing

Friedman, Y. (2008). Building Biotechnology: Business, Regulations, Patents, Law, Politics, Science. Logoss press.

Harris, J. (2003). Clone, gene si nemurire. Bucuresti: Curtea Veche

Moldovan, A. T. (2002). Medical Law Treaty. Bucuresti: All Beck

Reuter, L. (2003). Modern Biotechnology in Posmodern Times? A Reflection on European Policy and Human Agency.Dordrecht: Springer

Stoica Constantin \& Neculau. (1998). Psychology of conflict resolution. Iasi: Polirom

Tanasescu, I. et al. (2000). Elementary Treaty of Criminal Law and Criminology. Craiova: Sitech

Vasiu, I. (2004). Genetic manipulation. Criminal implications. Revista de Drept Penal, pp. 2 